\title{
Votes, Clientelism, and Conditional Cash Transfer Programs:
}

\section{A Case Study in Brazil}

\section{Fábio Mariano Espíndola da Silva}

Political Science undergraduate student at the Federal University of Pernambuco - UFPE. Recife, Brazil. (fabio.mes@gmail.com).

\begin{abstract}
Studies in the field of clientelism show that this specific social phenomenon can influence the voting patterns and local behavior in developing countries, maintaining in power a political elite that detains the vast majority of the local economic resources. Conditional Cash Transfer Programs - such as Bolsa Familia in Brazil - are designed to provide direct cash transfers from the government to the poor, in return for some conditions. Those programs represent an unexpected variable in the equation of clientelism - they provide an escape for clients from their patrons, with resources that no longer depend on the patron's approval. This paper pursues a hypothesis that the presence of Bolsa Familia changes the vote-seeking strategies of clientelistic patrons. Despite the theoretical evidences that this should be the observed, data analysis in a case study shows that empirical evidence is inconsistent and that further research on the matter should be pursued and improved.
\end{abstract}

Keywords: Brazil; Cash Transfer; Clientelism; Public Policy; Voting Strategy 


\section{Introduction}

There is a kind of relationship that unfolds at a variety of scales, in different countries of the world, based on ties of loyalty developed between dissimilar subjects, where one usually has the economic or political power and the other has some minor resource for supporting or maintaining the first in a position of superiority. To this relation was given the name of clientelism. The existence of clientelism has been studied for years by the literature, and many conceptual differences have been observed. It is a complex relationship that requires caution in study and analysis.

The establishment of conditional cash transfer programs in Brazil seems to have brought a fundamental change in the basic structure of loyalty that binds the relationship. This kind of public policy aims to distribute, among socioeconomically vulnerable people, a variable benefit according to the family structure, under some specific conditions. The goal would be to break the intergenerational cycle of poverty and promote inclusion of those individuals in the production and consumption chain. The effects on the social structure of these policies have been evaluated throughout its implementation by several authors. Their findings showed that income transfer programs played an important role in the recent reduction of inequality in Brazil.

However, another effect of the program, also already analyzed by Brazilian literature, was the establishment of new ties of loyalty from the population served by the policy directly with the figure of former president Lula da Silva. This new loyalty, coupled with the increase in income and, consequently, reduced inequality rates, especially in poorer regions, led to the basic question of this research: did the Bolsa Familia program - flagship of the social policies from the Federal Government - promote a change in clientelistic ties that united patrons and clients?

The results showed that the relationship between the voting parameters and scope of the program is difficult to establish, since there is no significant correlation between the compared numbers of both variables. The fundamental discovery rested on the finding of a recurring local political elite that adopts similar electoral strategies and remained apparently isolated from a more forceful influence of the program under their constituencies. Further studies are needed to elucidate the details found on this research.

\section{Clientelism}

The study of clientelistic relationships has evolved gradually, especially in countries more sensible to the phenomenon. Several authors have sought to define and limit its bases to deepen the knowledge about the formation of the unique ties that bind individuals from such different social backgrounds in a complex relationship of mutuality. The first scientific definitions of the 
phenomenon can be found in studies from British anthropologists and social scientists from a variety of nations in the 1950s, when researching about the existence of this kind of relationship in Mediterranean societies (Combes 2010). Inside Political Science, the patron-client relationship was primarily described as "a relationship of personal dependence that is not bound by kinship and which sits on reciprocal exchanges between people - patron and client - who control unequal resources" (Médard 1976).

With the existence of a patron and one or multiple clients, the phenomenon can be drawn in its traditional form, basically, as a particular kind of relationship where patron-client interaction networks are formed, based on social contexts of broad inequality in areas of low economic dynamic or even external economic isolation. While inequality helps to focus the economic resources in the hands of a small group - the patrons - sluggish development or economic isolation contributes to the reduction of alternative options for clients (Shami 2012).

A common misconception overlaps patronage and clientelism as being a single thing. They are alike, however conceptually different. The first one is referred to as the "use or distribution of state resources on a non-meritocratic basis, for political gain" (Mainwaring 1999). If, on the other hand, political clientelism is observed, four main features can be spotted: an unequal character, uneven reciprocity, a non-institutionalized nature, and face-to-face character (Mainwaring 1999).

Voters submitted to this relationship, in general, neglect the larger political spectrum in which they are inserted (Hopkin 2006) and the consequences their decisions in the voting booth may have for the community that will be represented. The important thing is to maintain the bonds of loyalty and pay back the benefit earned. This ultimately produces a reversal in the logic of traditional accountability: instead of voters using the important mechanism of vote to punish or reward political practices, candidates - and their parties - are to observe the behavior of their constituencies and reward or punish them accordingly ${ }^{73}$. To this inversion, Stokes (2005) gave the name of perverse accountability.

The Latin-American context, with all its complexity, requires a more careful analysis of the matter, beyond the numbers found in studies on vote buying. This implies primarily in the definition of political clientelism. The words of Auyero (1999) serve well in this regard, when stating that "political clientelism consists in the distribution of resources (or promise of) by political office holders or political candidates in exchange for political support, primarily although not exclusively - in the form of vote". This definition fits better to this study, since it is

\footnotetext{
${ }^{73}$ A classic example would be through distribution of public employment.
} 
less fixed than simply vote buying - adding the expression 'not exclusively' leaves an open remark, required when analyzing complex social relations.

The attempts to establish standards for measuring levels of clientelism encountered difficulties for slamming into the debate about what would be the ideal point of reflection on the origin and causes of the cited relationship. The studies that went ahead with measuring efforts, focused some on ethnographic case studies and others in qualitative analysis, with emphasis on surveys among clients (Stokes 2005, Auyero 2001; Levistky 2003, Schaffer 2007 cited in Ocantos 2012), which returned interesting however not universalized results. Quantitative studies are sparse, and the most prominent studied the allocation of resources through U.S. territory, in order to estimate the flow of selective benefits to certain localities (Frish 1998 cited in Hopkin 2006). However, the literature still seems to lack the proper tools to perform more precise measurements.

Party arrangements have a vital role in the development of clientelism (Mainwaring 1999). In contexts of strong and stable national authorities with a hegemonic party - or very few parties - that perpetuates itself in power for a considerable period of time, local leaders are discouraged from challenging the ruling party, since they obviously have fewer alternatives to it (Ansell, 2011). Along the same lines, but in the opposite direction, in arrangements where different parties enter and leave government more frequently, it is possible for local figures to become more prominent than a national institution, also making the alliances less rigid and party loyalty considerably decreased (Ansell 2011).

It is relevant to note that a variable is persistent in almost all the authors who have studied the matter: socioeconomic inequality between patron and client. Inequality becomes essential to the unfolding of clientelistic relations once it acts as a key factor for its formation without inequality, clients would be in a position of choice and could easily opt out of the relationship at a relatively low cost or even never have the need to engage in this type of social interaction. The bonds of loyalty still represent a relevant connection, but one that would not stand the test of overcoming socioeconomic inequality, in case the individual feels somehow jeopardized within the clientelistic relationship. Ceasing or considerably reducing inequality also reduces the effect of dependence and the individual can be free to make other political choices, as loyalty weakens - even if it is the choice to stay in the relationship (Shami 2012)

In research conducted to analyze the effects of clientelism in a democratic context - for majoritarian elections - on the adoption of redistributive policies, Medina and Stokes (2002) observed that the relationship produces a political monopoly that reduces, but does not eliminate, electoral competition, granting the incumbents high interest in suppressing the 
implementation of redistributive policies (Medina and Stokes 2002). The Medina and Stokes' (2002) model mathematically depicts an assertion already found for some time in qualitative literature that clientelism produces a political monopoly, however its conclusions could be drawn only for majoritarian elections.

The dyad inherent to the establishment of the loyalty ties requires an imbalance of economic power - and often political - between the sides. As incumbents have little interest in implementing redistributive policies - since those ensure a diversification of risk free activities and greatly reduce the bargaining power of patrons (Stokes 2002) - some change is expected in the fidelity bonds that connect patron and client, once a redistributive policy that have its structure weakly dependent on local bosses for fulfillment, is implemented. That is the case for conditional cash transfer programs, especially in Brazil.

\section{Conditional cash transfer programs}

Conditional cash transfer programs are developed aiming at the redistribution of income and wealth produced in a given country through reallocation of resources from the central government - and in some cases local - to a certain category of individuals, ranked by income by legislation, focused on the reduction or reversal of socioeconomic vulnerability under certain conditions to break the intergenerational cycle of poverty. Development and advance of those programs have had Latin America and the Caribbean as a starting point, and where the most prominent and successful examples can be found (ISSA 2008).

Brazil adopted, by the end of 2003, Family Stipend - or Bolsa Familia, a program created to correct the flaws of previous CCT programs, aiming at the poorest to alleviate general poverty. It was planned as a master-program that would embrace other welfare and conditional cash transfer programs under unified ministry command, making its implementation more coordinated and efficient.

The beneficiaries of Family Stipend are those citizens classified by two income levels considered by the legislation: the extremely poor and the poor. Small grants are distributed according to those classifications. As a condition to the benefit earned, the design of the policy requires beneficiaries to fulfill certain conditions relating to prenatal examination, nutritional counseling, health monitoring and school attendance of 85\% minimum (eighty five percent). The logic in demanding these requirements is that focusing on children and adolescents, the 'accumulation of human capital can help break the intergenerational transmission of poverty' (Hall 2006). 
Altogether with other key economic aspects - like a real increase in the minimum wage in the first decade of the twentieth century, the expansion of credit and a consistent reduction in unemployment rates - the program resonated positively to the increase of social mobility and reduction in absolute poverty levels from $28 \%$ to $23 \%$ (Castro et al. 2010) and, although extensively broad, the program is relatively cheap for the Federal Government, costing only $0.4 \%$ of GDP in 2011 figures (Hall 2012).

The impact of Family Stipend on the inequality indexes has already been described by specialized literature. Vaz (2012) gives an extensive analysis of five social indicators ${ }^{74}$ to assess the effect of PBF on reducing socioeconomic inequality. The results found that, for all indicators examined, there was a significant reduction in the "incidence, intensity and hence the severity of poverty and extreme poverty" (Vaz 2012) with a constant and systemic decline, attributed in large part, to the highly focused strategy of the Family Stipend. There is a reminder, repeated on this and many other studies on the subject, that the macroeconomic context of the country also contributed significantly in reducing the levels of aggregate inequality, but its impact on the focal range of the program's income is considerably reduced by the fact that these families are, overwhelmingly, excluded from the production chain and thus less sensitive to economic changes. Other authors observed similar results (Januzzi, Martignoni and Souto 2012, Soares and Satyko 2009). Nevertheless, there is a steady decline in the leading indicator of inequality, during the analyzed time series, as shown in figure 1.

The Unified Registry System, that houses data from all beneficiaries of the Family Stipend, was redesigned in 2004 with the implementation of the program, and gave to municipalities - hence to local elites - the assignment to register families and consequently include them in the system, dismantling the previous elected selection committees and granting mayors control over the selection of beneficiaries (Ansell 2011, Hall 2006).

It is arguable the real extent that this control returned to mayors - with decentralization - actually meant in terms of material for possible clientelistic bargains. The Family Stipend had no limited slots nor budget limitations to families: the number of families to be benefited would, in theory, be endless - it was enough that beneficiaries were categorized into socioeconomic boundaries described by law and included in the Unified Registry system, to receive the benefits. The cost of adding a new family in the system was null for the mayor - since the funds came from the federal government anyway - and the negative effect of a mayor's misconduct before his own electorate, by not registering in a few families, while most received the benefit, would be

\footnotetext{
${ }^{74}$ Gini Coefficient, Atkinson Coefficient, Theil Coefficient, Medium Extreme Poverty Gap and Severity of Extreme Poverty.
} 
too high to be ignored (Ansell 2011), leading them to register families, even without the prospect of electoral bargaining. In the end, although local elites possess discretion over the selection of beneficiaries, the perception of voters fell directly on the Federal Government, in the person of the now former president Lula da Silva, as the main provider. This led, to a certain extent, to a primary dislocation of previous bonds from local clientele networks with the local patron to an early migration for a broader form of personalistic clientelism, focused on the President.

Some of those electoral effects of Family Stipend for the President, have been studied in many papers (Hunter and Power 2007, Nicolau and Peixoto 2007, Soares e Terron 2008 cited in Castro, Lício, and Rennó 2009), and found strong evidence correlating the vote in Lula, in his 2006 reelection, with being a recipient of the program. The authors, though cautious to assert causality of this correlation, emphasized that the statistical reading seemed to point to a preference for candidates who performed redistributive policies, especially Lula da Silva. In the same line, but emphasizing individual perception of voters, Castro, Lício and Rennó (2009) found consistency, in the 2006 presidential election, with being a recipient of Family Stipend not only with the vote in the former president, but also the positive evaluation of his government and his work at the office. These studies bring to the surface the notion that socioeconomic changes resulting from the implementation of Family Stipend had resounding electoral effects on the federal majoritarian elections.

\section{The Brazilian electoral system, clientelism and Family Stipend}

Brazil aligns itself with the group of countries in the world that adopts a system of proportional representation for the selection of candidates to fill seats in the legislative chambers. The electoral districts are multi-member and defined by the federated states' borders, therefore having a relatively high number of voters - most sharing very different realities within the same district. The Brazilian proportional representation system uses an open party list to allocate the recipients of legislative seats assigned to each party after the elections. This configuration, by itself, tends to considerably increase the weight of the figure of the candidate in the final outcome of the election (Dalton and Anderson 2011), and the Brazilian system maximizes this tendency (Ames 2001). Candidates are free to select any part of the electorate to focus their campaigns and strategies during the elections, however, as identified by Ames (2001), most of them boils down to garner votes in a limited number of municipalities.

Consequently, the spatial patterns of votes for a legislative chair vary in two dimensions, identified by Ames (2001): the dominance-sharing, or vertical penetration in municipalities, and 
the concentration-dispersion, or horizontal coverage. The author describes the first dimension as follows:

"Suppose, for every candidate in each municipality, Vix, candidate $i$ 's share of all the votes cast in municipality $x$, is calculated. Each candidate's municipal dominance is defined as the candidate's share of the total votes cast for members of all parties. These shares represent the candidates' dominance at the municipal level. Now suppose Vix is used to calculate Di, the average dominance for each candidate across all the state's municipalities, weighted by the percentage of the candidate's total vote each municipality contributes. Candidates with higher weighted averages tend to dominate their key municipalities; those with lower weighted averages share their key municipalities with other candidates. Thus Dominance-Sharedness is the first dimension of spatial support.” (Ames 2001).

The second dimension observed by Ames (2001) refers to the parameters of concentration-dispersion of votes for each candidate within the district. In this perspective two distinct voting profiles would be identified: one with a dispersed pattern throughout the state and the other with the votes concentrated in a small number of municipalities. Analyzing the work of Ames (2001), Avelino, Biderman and Silva (2011) explained that "opposed to the single district systems - in which candidates pursue the majority of voters - in proportional representation systems, reelection would be possible if the deputy was able to ensure small, but faithful, slices of the electorate".

Avelino, Biderman and Silva (2011) discussed the calculation methodology of Ames and reached the conclusion that its content could not resist a simple counterfactual test: in case of perfect dispersion of the votes, the measure should return a null value, which did not happen. They decided to adopt a new index for the concentration/dispersion dimension, adapted from regional and urban economics and originally used to measure the contribution of a region to the total output of the economy: the G index (Pinto 2013). This index is easily maneuverable and it "deducts from the observed votes for a given candidate, the total votes that would be expected from this candidate, had his votes been cast in a random distribution among the municipalities" (Avelino, Biderman, and Silva 2011). It ranges from $G=0$ to $G=2$, where 0 corresponds to a perfectly dispersed spatial distribution, and 2 to a perfectly concentrated. Moreover, the importance of the municipality in the total amount of votes in the district is also weighted by the index, making that perfect values of $G=2$ are allocated to candidates who not only got all of their votes in only one municipality, but this municipality also has a disproportionate weight when compared to others (Pinto, 2013).

Therefore, the municipality, for many legislative competitors in Brazil, is the unofficial stage of electoral disputes. Being a local leader, being born in a traditional family or establish 
agreements with local incumbents can be crucial in securing the necessary votes to win an election. Further restructure of the Unified Registry system, returning selection of beneficiaries prerogatives to the mayors could have even accelerated this process, with an increase in bargaining power of local leaders.

The introduction of Family Stipend elevated income - with the credit for the implementation shifted to the federal government. This circumstance, added to the fact that clientelism, in Brazil, is of the bossism type, and not corporatist, could lead to a dual impact over local clientelistic bonds: 1) There is a possible lapse of electoral loyalty among clients, dedicated before to local patrons, which now falls on the figure of the president and his party - as attested by previous studies (Castro, Lício, and Rennó 2009); 2) Assuming that politicians are rational, those who possess clientelistic attributes, faced with this change of loyalty, could have altered their spatial vote distribution strategies, aiming in spreading their electorate throughout the district, instead of concentrating efforts in municipalities where they are, slowly, loosing electoral loyalty. This process would have been deepened by the reduction of inequality between patrons and clients, brought by the implementation of the program and consequent rise in income that could promote a significant imbalance in client-patron relations.

Once the logic found in the literature asserts that traditional clientelistic bonds are set in highly unequal societies and restricted economies, taking into account that the adoption of Family Stipend returned an alteration - to a greater or lesser degree - in income and levels of inequality in most municipalities where it was implemented, observing that voters recognized and credited the importance of the program do the Federal Government, under the figure of President Lula, and counting that political actors are rational, a fundamental question was raised: are the two dimensions of spatial distribution of votes, affected in any way by the implementation of the Family Stipend program?

\section{Methodology}

Evaluating the impact of a social program on clientelistic ties proved to be a challenge. The complexity of the relation was too deep to be reduced to simple numbers of vote buying, so a new approach was considered. It consisted in observing the spatial patterns of votes from winning candidates in three elections $(2002,2006$, and 2010) to the local state parliament and to the Federal House of Representatives, in a case study prior and during the implementation of the Family Stipend program. Only the winners were chosen so that it could be perceived how the evolution of the program impacted on their consecutive elections, and that could only be achieved with recurring candidates. Ames' study (2001) guided this part of the research, since his 
findings identified four different patterns within the two dimensions of spatial vote distribution, and one of them strongly consistent with clientelism. The goal was to seek among the sample for the pattern that matched clientelism: Concentrated and Dominant.

The assertion in the literature is that the more clientelistic a candidate is, the more he or she will try to concentrate his or her votes on a limited number of municipalities and to dominate the local vote counting by having an expressive proportion of the municipalities' $\operatorname{votes}^{75}$. Knowing this, the two dimensions of the clientelistic-identified parameter were separated: Concentration-Dispersion and Dominance-Sharedness. The first was analyzed by comparing the $G$ index numbers from the candidates to observe the behavior of this dimension trough time - it was expected that it had shifted from a concentrated pattern, to a more dispersed one. To perform the analysis of the second dimension, a primary correlation was developed $^{76}$ : Between the number of beneficiaries from the program and candidates' Dominance rates for each election in which the program was already in course. I expected to find a negative correlation between being a beneficiary of the program and the Dominance each candidate exerts in the municipality, based on the theoretical studies. Since correlation does not imply causation, had the correlation returned significant results, I would have proceeded with more advanced statistical analysis to control other variables and observe how the sample would behave, and draw conclusions from there. This, unfortunately, was not the case.

Choosing Brazil and, within it, the state of Pernambuco, was strategic. In Latin America, Brazil has the largest conditional cash transfer program, with massive numbers of beneficiary families, plus a continental dimension that embraces a multiplicity of realities - an important condition for the development of a study that seeks to interact with clientelistic relations. Inside Brazil, when analyzing data from the implementation of Family Stipend, two regions stood out in terms of percentage of population served: the North and Northeast regions (MDS 2014). The Northeastern region has had historical clientelistic past and is composed by 9 federated states, being the state of Pernambuco selected among them using the typical case technique, which, according to Gerring and Seawright (2008), “uses a representative case of some phenomenon so that the researcher can better explore the causal mechanisms at work in a general, cross-case relationship". Since measuring clientelism is still a defiant task, sociodemographics were used to

\footnotetext{
75 That is the pattern identified by Ames (2001) with being consistent with clientelism.

${ }^{76}$ Using IBM’s SPSS v. 20, 2011.
} 
scanner for the most representative state. Data showed that the target group ${ }^{77}$ of Family Stipend ${ }^{78}$ was closer to the region's average in Pernambuco state.

To evaluate the dimension of Family Stipend in Pernambuco's municipalities, the number of families that received the Family Stipend benefit, reasoned by the population, in each municipality (Fpbf), gave a panorama of the range the implementation had in the state. Since the program only began in 2004, the data collected ranges from 2004 to 2010.

The candidates were divided into two groups, depending on their legislative posts - Df, for the Federal Deputies and De for State Deputies. In the operationalization of the analysis, it was calculated: 1) the dominance rates of each candidate in the two groups, for each municipality, for the 3 selected elections; 2) the $G$ index for all candidates in the two groups, on the 3 selected elections.

In practice, the dimensions of spatial distribution of votes were used as a proxy of clientelism. It must remain clear that this is not the most appropriate or accurate tool to measure such a complex phenomenon, but it is operationally acceptable to choose a proxy when trying to represent an abstract, hence difficult to measure, concept, in cases of transmutation of those in quantitative variables (Figueiredo and Silva 2010).

\section{Results ${ }^{79}$}

The initial $\mathrm{N}$ values considered for the groups already shows how high the renewal rates are, for both positions, during the time period analyzed. The total universe of elected candidates in Pernambuco in 2002 was 23 Federal deputies and 43 state deputies, which returns renewal rates of $74 \%$ for federal seats and $77 \%$ for the states' parliament, since only about a quarter of them managed to reach the 2010 election.

From the analysis of Tables 1 and 2, with the values for the $G$ index for both groups, it can be inferred that the winning electoral strategy, in Pernambuco, for legislative elections, seems to aim at the dispersion and not concentration, contradicting the prediction of Ames' studies (2001). Index values returned much lower numbers than expected in a state with historical features associated with clientelism and demonstrated that the initial hypothesis that winning candidates presented a more concentrated strategic profile and would subsequently disperse it through the influence of the program, in order to guarantee their votes, can now be moved aside by preliminary data. The discovery, however, is significant: the number of deputies, whether state

\footnotetext{
${ }_{77}$ The target group of Family Stipend also coincides with the parcel of the population more subjected to clientelistic bonds. For this reason, sociodemographic data played a very important role in case selection.

${ }^{78}$ Families with per capita monthly income below $\mathrm{R} \$ 70,00$ and those between $\mathrm{R} \$ 70,01$ and $\mathrm{R} \$ 140,00$.

${ }^{79}$ Database available at Silva (2014).
} 
or federal, who managed to get elected, did so by dispersing their votes. It can not be affirmed, with only the data collected at the research, whether the reason that led them to win was precisely because of dispersion strategies, however there are indications in the work of Pinto (2013) and Avelino, Biderman and Silva (2011), that the decentralized strategy tends to be more successful.

The Dominance-Sharedness dimension was analyzed through a correlation that returned non-significant values. So, it can be interpreted that there are no relevant correlations, in Pernambuco state, for winning legislative candidates, between the amount of families served by Family Stipend and nominal votes or dominance that candidates exert at local municipalities.

It is very important to emphasize that the results do not attest that there is no relationship between Family Stipend and state legislative votes, it simply points out that the figures can not be correlated, which serves as an indication to point out that there may be no relevant influence of the program on voting strategies and that the politicians analyzed did not return spatial voting parameters consistent with clientelism. It is clear that the final result may have been influenced by the selection of the sample - only winning candidates. The expansion of this research to other states, and possibly other countries, will include a larger number of elections, more complex explanatory variables, and a sample that covers all candidates, which could return safer values and more universalizing claims.

The most important finding of this work, however, resided in the detection of a state political elite that remained apparently indifferent to the adoption of such a relevant policy as Family Stipend. Understanding who these actors are, how they act and why they form this elite not only in Pernambuco, but throughout the country and the continent - is of paramount importance for a better understanding of the Brazilian political system and further comprehension of the complex patron-client relationship.

\section{Concluding Remarks}

The article aimed to elucidate, through the spatial parameters of votes for seats in the state and federal legislature, with a case study, if there was a possible interaction between the main social program in the Americas and local state politics, for the legislative branch. The results pointed to a weak influence of Family Stipend in spatial parameters of voting, most likely influenced by the sample.

The effects and potential impacts of social policies, especially conditional cash transfer programs, are only now beginning to be understood through data and more complex analysis. Numbers expressing voting preferences, reduction in inequality, and the emergence of a new 
social class are everywhere and help to understand the scale of change that these policies may have on the population.

Clientelistic relations are a complex phenomenon. Its attributes and the leading cause for those involved to engage in this kind of relationship have been described and elucidated by the qualitative literature. The main challenge that persist, rests on quantifying and setting measurement parameters, not only in detecting its existence, but also on the implications over social structures. The attempt to unite and correlate both the social relation and the public policy ran exactly on this measurement obstacle.

The existence, however, of a political elite with a moderately similar spatial parameter of vote, and apparently not largely susceptible to an influence from the conditional cash transfer program of the federal government, is a remarkable finding and initiated a series of questions and attempted clarifications to be developed for a future research agenda. The potential for expanding the study with replication in other states and countries, leaves an open door for further scientific development around the matter. 


\section{References}

Ames, Barry. The Deadlock of Democracy in Brazil. Ann Arbor: University of Michigan Press, 2001.

Ansell, Aaron, and Ken Mitchell. "Models of Clientelism and Policy Change: The Case of Conditional Cash Transfer Programmes in Mexico and Brazil". Bulletin of Latin American Research 30. No. 3 (2011): 298-312.

Auyero, Javier. ""From the client's point(s) of view": How poor people perceive and evaluate political clientelism". Theory and Society 28(1999): 297-334.

Avelino, George, Ciro Biderman, and Glauco Peres da Silva. "A Concentração Eleitoral nas Eleições Paulistas: Medidas e Aplicações”. DADOS - Revista de Ciências Sociais, 54, No 2 (2011): 319-347.

Brasil. MDS - Ministério do Desenvolvimento Social e Combate à Fome. "Institucional e Acesso à Informação” - http://www.mds.gov.br/acesso-a-informacao (accessed October 2013).

Brasil. TSE - Tribunal Superior Eleitoral. "Estatísticas do Eleitorado Brasileiro nas Eleições de 2010" - http://www.tse.jus.br/eleicoes/eleicoes-anteriores/eleicoes-2010/estatisticas (accessed August 2013).

Castro, Henrique Carlos de O., Elaine Cristina Licio, and Lucio R. Rennó. "Bolsa Família e Voto na Eleição Presidencial de 2005: em busca do elo perdido”. Opinião Pública, 15, No 1. (June, 2009): 31-54.

Castro, Jorge Abrahão de, Helder Rogério Sant'Ana Ferreira, André Gambier Campos, and José Aparecido Carlos Ribeiro (Eds.). Perspectivas da política social no Brasil. Brasília: Ipea, 2010

Combes, Helène. “¿Dónde estamos con el estudio del clientelismo?” Desacatos 36 (Mayo Agosto 2011): 13-32.

Dalton, Russel J., and Christopher J. Anderson. "Citizens, Context, and Choice: How Electoral Context Shapes Citizens’ Electoral Choices”. New York: Oxford University Press, 2011.

Figueiredo Filho, Dalson Britto, and José Alexandre da Silva Júnior. "Visão além do alcance: uma introdução à análise fatorial”. Opinião Pública 16 No 1 (June, 2010): 160-185.

Gerring, John, and Jason Seawright. "Case Selection Techniques in Case Study Research: A Menu of Qualitative and Quantitative Options”. Political Research Quarterly 61(2008): 294-310.

Hall, Anthony. "From Fome Zero to Bolsa Família: Social Policies and Poverty Alleviation under Lula” Journal of Latin American Studies 38 No 4 (November, 2006): 689-709.

. "The last shall be first: political dimensions of conditional cash transfers in Brazil" Journal of Policy Practice 11 (2012): 25-41.

Hopkin, Jonathan. "Clientelism and Party Politics". In Handbook of Party Politics, edited by Richard S. Katz and William Crotty, 406-412. London; Thousand Oaks, Calif.: SAGE, 2006. 
IPEA - Instituto de Pesquisa Economica Aplicada. "IpeaData". Online database of Brazil's Social Indicators - http://www.ipeadata.gov.br (accessed August 2013).

ISSA - International Social Security Association. "Social Security Programs Throughout the World: The Americas, 2007”. Washington, DC: Office of Social Security Administration, 2008.

Januzzi, Paulo de Martino, Enrico Moreira Martignoni, and Baiena Feijolo Souto. "Programa Bolsa Família e sua contribuição para a redução da pobreza no Brasil" In Revista Brasileira de Monitoramento e Avaliação 4 (Jan-Jun, 2012): 40-61.

Kitschelt, Herbert, and Steven Wilkinson (eds.). Patrons, Clients and Policies. Cambridge: Cambridge University Press, 2007.

Leal, Victor Nunes. Coronelismo, Enxada e Voto. São Paulo: Companhia das Letras, 2012

Mainwaring, Scott. Rethinking Party Systems in the Third Wave of Democratization: The Case of Brazil. Stanford, Calif.: Stanford University Press, 1999.

Médard, Jean-François. "Le rapport de clientèle: Du phénomène social à l'analyse politique". Revue Française de Science Politique 26 núm. 1 (1976): 103-131.

Medina, Luis, and Susan Stokes. "Clientelism as Political Monopoly". Paper presented at the annual meeting of the American Political Science Association. Boston, MA, August 28, 2002.

Ocantos-Gonzalez, Ezequiel, Chad Kiewiet de Jonge, Corlos Mléndez, Javier Osorio, and David W. Nickerson. "Vote Buying and Social Desirebility Bias: Experimental Evidence from Nicaragua”. American Journal of Political Science. Vol. 56. No. 1 (January, 2012): 202-217.

Pase, Hemerson Luiz, Matheus Müller, Jennifer Azambuja de Morais. "O clientelismo nos pequenos municípios brasileiros”. Pensamento Plural, n. 10 (Janeiro/Junho, 2012): pp 181-199.

Pinto, Rodolfo Vieira de Melo da Costa. "Estratégias eleitorais: Concentração e dispersão nas eleições para deputado federal em Pernambuco". Graduation thesis presented at the Federal University of Pernambuco. Recife: Universidade Federal de Pernambuco - UFPE, 2013.

Robinson, Jonathan. "Measuring Political Clientelism: The Systematic Qualitative Approach". Paper presented at the 2008 Annual Meeting of the MPSA Annual National Conference. Chicago, IL, 2008.

Shami, Mahvish. "Collective Action, Clientelism, and Connectivity". American Political Science Review. Vol. 106. No. 3. (August, 2012): 586-606.

Silva, Fabio. "Legislative Election Data from Pernambuco State - 2002, 2006, and 2010". Harvard Dataverse Network, V1 (2014) -http://dx.doi.org/10.7910/DVN/25595 (accessed January 2014).

Soares, S. and Satyko, N. O Programa Bolsa Família: desenho institucional, impactos e possibilidades futuras. Brasília: IPEA, 2009. 
Stokes, Susan. "Perverse Accountability: A Formal Model of Machine Politics with Evidence from Argentina”. American Political Science Review. Vol. 99, No 3. (August, 2005): 315-325.

Vaz, Alexander Cambraia N. "Efeitos do Programa Bolsa Família sobre a desigualdade e a extrema pobreza: análise e evidências a partir do Censo Demográfico 2010”. In Revista Brasileira de Monitoramento e Avaliação. No. 3 (2012): 76-95.

Veloso, Giovana Rocha. "Clientelismo: uma Instituição Política Brasileira”. Master Thesis presented at the University of Brasilia. (September 6). Brasília, DF, 2006. 


\section{Appendix}

Figure 1: Gini Coefficient - Brazil (2002 - 2012)

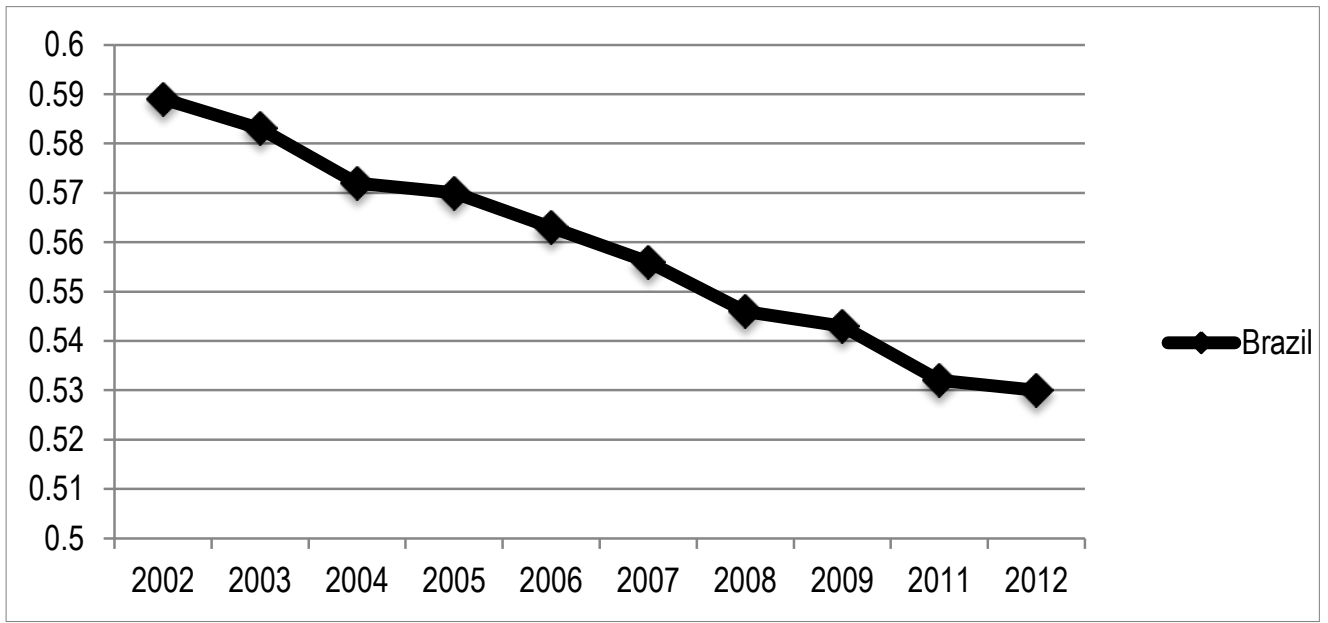

Source: IpeaData (IPEA, 2013). Prepared by the author.

\section{TABLE 1: G index for candidates on group De}

\begin{tabular}{|c|c|c|c|}
\hline CANDIDATE & 2002 & 2006 & 2010 \\
\hline ANTONNIO DE MORAIS ANDRADE NETO & 0,067791678 & 0,0678322 & 0,059522585 \\
\hline $\begin{array}{l}\text { GUILHERME ARISTOTELES UCHOA CAVALCANTI } \\
\text { PESSOA DE MELO }\end{array}$ & 0,1081596 & 0,095742616 & 0,068307547 \\
\hline ISALTINO JOSE DO NASCIMENTO FILHO & 0,127399508 & 0,087323485 & 0,064181094 \\
\hline JOSÉ AGLAILSON QUERÁLVARES JUNIOR & 0,201325376 & 0,156411731 & 0,17977936 \\
\hline JOSÉ FERNANDO PONTUAL COUTINHO & 0,07840588 & 0,087415786 & 0,050327961 \\
\hline $\begin{array}{l}\text { JOSÉ RAIMUNDO PIMENTEL DO ESPÍRITO } \\
\text { SANTO }\end{array}$ & 0,261030341 & 0,134739068 & 0,153961408 \\
\hline MARCANTONIO DOURADO & 0,150144109 & 0,15232543 & 0,120277008 \\
\hline MAVIAEL FRANCISCO DE MORAES CAVALCANTI & 0,068525293 & 0,074788188 & 0,069433853 \\
\hline SEBASTIÃO IGNÁCIO DE OLIVEIRA JÚNIOR & 0,14053114 & 0,113349557 & 0,095958793 \\
\hline SÉRGIO JOSÉ LEITE DE MELO & 0,096181986 & 0,117920256 & 0,109731298 \\
\hline AVERAGE & 0,129949491 & 0,108784832 & 0,097148091 \\
\hline
\end{tabular}

Source: Author. 
TABLE 2: $G$ index for candidates on group $D f$

\begin{tabular}{lccc}
\hline CANDIDATE & $\mathbf{2 0 0 2}$ & $\mathbf{2 0 0 6}$ & $\mathbf{2 0 1 0}$ \\
\hline $\begin{array}{l}\text { CARLOS EDUARDO CINTRA DA COSTA } \\
\text { PEREIRA }\end{array}$ & 0,02383386 & 0,051558141 & 0,032544439 \\
FERNANDO DANTAS FERRO & 0,02756431 & 0,019707232 & 0,029674474 \\
INOCÊNCIO GOMES DE OLIVEIRA & 0,052543198 & 0,054784709 & 0,05376379 \\
JOSÉ SEVERIANO CHAVES & 0,041236821 & 0,042423089 & 0,029407633 \\
LUIZ GONZAGA PATRIOTA & 0,132955823 & 0,093415418 & 0,112443895 \\
MAURÍCIO RANDS COELHO & 0,081296944 & 0,018196733 & 0,020378127 \\
\hline AVERAGE & $\mathbf{0 , 0 5 9 9 0 5 1 5 9}$ & $\mathbf{0 , 0 4 6 6 8 0 8 8 7}$ & $\mathbf{0 , 0 4 6 3 6 8 7 2 6}$ \\
\hline
\end{tabular}

Source: Author. 